Article

\title{
Considerations on Field Methodology for Macrofungi Studies in Fragmented Forests of Mediterranean Agricultural Landscapes
}

\author{
Abel Fernández Ruiz ${ }^{1}$, David Rodríguez de la Cruz ${ }^{1,2} *\left(\mathbb{D}\right.$, José Luis Vicente Villardón ${ }^{3}(\mathbb{D}$, \\ Sergio Sánchez Durán ${ }^{4,5}$ (D) Prudencio García Jiménez ${ }^{1}$ and José Sánchez Sánchez ${ }^{1,2}$ \\ 1 Institute for Agrobiotechnology Research (CIALE), Universidad de Salamanca, Río Duero 12, \\ 37185 Villamayor, Spain; abel@usal.es (A.F.R.); prudenciogarjim@gmail.com (P.G.J.); jss@usal.es (J.S.S.) \\ 2 Department of Botany and Plant Physiology, Universidad de Salamanca, Licenciado Méndez Nieto s/n, \\ 37007 Salamanca, Spain \\ 3 Department of Statistics, Campus Miguel de Unamuno, Universidad de Salamanca, Alfonso X El Sabio s/n, \\ 37007 Salamanca, Spain; villardon@usal.es \\ 4 Unidad de Recursos Forestales, Centro de Investigación y Tecnología Agroalimentaria de Aragón (CITA), \\ Avda de Montañana 930, 50059 Zaragoza, Spain; ssanchezd@cita-aragon.es \\ 5 Instituto Agroalimentario de Aragón IA2 (CITA-Universidad de Zaragoza), 50013 Zaragoza, Spain \\ * Correspondence: droc@usal.es; Tel.: +34-677-584-172
}

check for updates

Citation: Fernández Ruiz, A.; Rodríguez de la Cruz, D.; Vicente Villardón, J.L.; Sánchez Durán, S.; García Jiménez, P.; Sánchez Sánchez, J. Considerations on Field Methodology for Macrofungi Studies in Fragmented Forests of Mediterranean Agricultural

Landscapes. Agronomy 2022, 12, 528. https://doi.org/10.3390/

agronomy 12020528

Academic Editor: Adamo

Domenico Rombolà

Received: 12 January 2022

Accepted: 18 February 2022

Published: 20 February 2022

Publisher's Note: MDPI stays neutral with regard to jurisdictional claims in published maps and institutional affiliations.

Copyright: (C) 2022 by the authors. Licensee MDPI, Basel, Switzerland. This article is an open access article distributed under the terms and conditions of the Creative Commons Attribution (CC BY) license (https:// creativecommons.org/licenses/by/ $4.0 /$ )

\begin{abstract}
The methodology used for the determination of macrofungal diversity in Mediterranean areas differs in the time of sampling and the number of years displayed, making it difficult to compare results. Furthermore, the results could be refuted because the studies are being conducted over an insufficient number of years or without considering the variation of the meteorological conditions from one year to the next and its effects on fruiting time, which might not fit the sampling. In order to optimize field work on fungal fruiting in Mediterranean environments dominated by holm oak (Quercus ilex L.), a weekly field analysis of macrofungal diversity from February 2009 to June 2013 was carried out in a Mediterranean holm oak forest in the middle-west of the Iberian Peninsula. The results revealed that fruiting bodies appeared throughout the year and that there was a delay in autumn fruiting, overlapping with spring. All this seems to indicate that weekly collection throughout the year and for a period of two years could be sufficient to estimate the macrofungal biodiversity of this ecosystem.
\end{abstract}

Keywords: macrofungi; field sampling; fungal diversity; Mediterranean forests; Quercus ilex

\section{Introduction}

It is estimated that the number of fungal species on earth is between 5.1 and 6.0 $M[1,2]$. Fungal species play an essential role in forest ecosystems, whether they act as decomposers, parasites, pathogens or mutualists [3]. Studies on ecology and fungi have traditionally focused on fungi that form macroscopic spore-producing structures, thus called macrofungi, as opposed to microfungi and their microscopic reproductive structures [4]. There are a large number of papers dealing with fungal diversity and the ecological aspects derived from it in temperate ecosystems [5-7]. However, little is known about the composition and structure of the fungal communities in holm oak-dominated forests (Quercus ilex subsp. ballota (Desf.) Samp.) that characterize much of the western landscape of the Mediterranean basin [8]. The agricultural landscape of the Mediterranean Sea basin is made up of numerous plots of continuous crop formations, both arable and woody, interrupted by forest formations [9]. In many cases these forest communities are relict forest ecosystems that used to shape the landscape. The intensification of cultivation in recent centuries has contributed to a greater homogeneity of the landscape, although some traditional patches dominated by tree species have been maintained due to various 
forestry or livestock uses [10]. The existence of these small woodlots is of great interest for a possible natural succession and conversion of disturbed ecosystems [11]. In addition, some of these residual isolated forests in the landscape could contribute to the design of future ecological corridors [12]. The performance of these fragmented forest formations is affected by various ecological processes linked to adaptation and acclimation, including, among others, plant-fungus interactions [13]. The diversity of soil fungi promotes numerous functionalities in forest ecosystems, not only the decomposition or recycling of nutrients, but also increasing their productivity and providing a better response to environmental stress [14].

One of the reasons for the little knowledge of macro-fungal communities in Mediterranean holm oak-dominated forests could be that this type of study requires several years of work due to the influence of meteorological variations on fungal fruiting [15]. In addition, the complexity is increased by the heterogeneity of the methods used, particularly the sampling frequency and different time periods.

Regarding the sampling period, early work revealed that the main period of fungal fruiting was concentrated in autumn [16], noting that environmental factors could explain the results of diversity obtained in several consecutive study years [17]. Other studies advised concentrating the estimation effort in the season of maximum production, since with weekly frequency it was possible to register $75 \%$ of the total production [18]. Most of the studies on fungal diversity in Mediterranean ecosystems are based on these results obtained for temperate ecosystems. Other researchers worked on personal observations not based on previous working hypotheses, which restrict collections at certain times of the year [19-21].

The conclusions obtained in a specific ecosystem could not be premises for others, and the quantitative methods based on fungal production may not be assumptions for qualitative studies of absence/presence. On the other hand, previous studies [17,18], when carried out in autumn or during the peak production period, took into account (i) the significant changes that the meteorological conditions cause not only in the fungal life cycle, but also in the composition of the community, and (ii) the seasonal fluctuations in the appearance of the fruiting bodies throughout the year, which could even go so far as to not occur $[8,22]$. Seasonal weather conditions varied significantly and successively on the planet during recent decades and could be related to these observations. These changes appear to be due to a rapid anthropogenic climate change [23] with a delay in autumn fruiting, a spring advance and a shorter duration of fruiting [24,25]. As noted above, most studies of macrofungal diversity for Quercus ilex L. in the Mediterranean area focused on a time of the year considered to be of maximum fungal fructification, the autumn. However, these studies do not consider if the new meteorological conditions have consequences in terms of the period of fructification and pay little attention to the specimens collected during summer and winter. The methodology used could be refuted, partially or totally, to the detriment of the results obtained.

Another problem when comparing studies is the different number of years invested in their development and the level of intensity. The patterns of variation in the latitudinal fungal distribution, its abundance, and the possible drivers of these patterns are insufficiently known $[1,26]$. However, several studies indicate that fungal communities have a fairly variable taxonomic composition over small distances. This high level of spatial variation has been attributed to the irregular development of fungi, to the natural heterogeneity of the resources in the soil matrix [27,28], and to fine-scale spatial variations [29]. Estimating fungal diversity in an ecosystem is an expensive and slow process which requires several years to record most of the species present [30-32] until the species accumulation curve reaches an equilibrium [33]. Another study [34] analyzed collections made during 30 years in one ecosystem, finding that the species accumulation curve began to level after six years, then grew more slowly and stabilized, reaching a plateau after 19 years. Therefore, and according to this work, it would take about 20 years to know the fungal biodiversity of an ecosystem, which is too high of an economic cost to carry out any study. The number of 
years used in the works reviewed for Mediterranean ecosystems differs, varying from a single year [35], through two [36], three [37], four [8,19,38] to twelve years [21].

The main aim of this work is to estimate the minimum number of years needed to know the macrofungal diversity in a Mediterranean ecosystem dominated by the holm oak. To this end, weekly transects were carried out over four years, eliminating, a priori, seasonal estimation errors and paying attention to the appearance of fruiting bodies in the months theoretically more adverse to fungal fructification. Other objectives considered were to know if it is possible to compare the data obtained in studies that have used a different number of years, and to check if restricted samples to the autumn are able to characterize the fungal biodiversity.

\section{Materials and Methods}

\subsection{Study Area}

The Forest of La Orbada is located in the middle-west part of the Iberian Peninsula $\left(41^{\circ} 8^{\prime} 0.48^{\prime \prime} \mathrm{N}, 5^{\circ} 29^{\prime} 0.01^{\prime \prime} \mathrm{W}\right)$ at an altitude of $820-856$ m.a.s.l. It consists of a set of plots of mature holm oaks with a shrub stratum formed by Cistus ladanifer L., Rosa canina L., Lavandula stoechas Lam., Daphne gnidium L., Thymus mastichina L. and Thymus zygis Loefl. ex. L. Geologically it is composed of sandstones and conglomerates-tertiary sediments (Priabonian age), which rest on a Paleozoic plinth formed by granites and rocks of the Cambrian and Siluric, thin detritic packages, strongly reddish, where thick sandstones are very abundant [39]. This area has a flat topography and Luvisol calcium soil type (reddish-brown soil, with silica gravel), with poor regular drainage [40]. The $\mathrm{pH}$ of the soil ranges between 6.6 and 7.2 [41]. The climate is temperate continental cold with a dry season of two months [42], induced by the combined effect of altitude, length and orographic insulation. This climate is characterized by cold winters, relatively cool summers, a superior annual thermal oscillation at $17^{\circ} \mathrm{C}$ and an annual rainfall of $372 \mathrm{~mm}$. The average annual temperature is $12.2^{\circ} \mathrm{C}$, January is the coldest month with average temperatures around $4{ }^{\circ} \mathrm{C}$, and July the warmest with an average temperature of about $21.5^{\circ} \mathrm{C}$ [43].

\subsection{Data Collection}

A plot of forest land with an area of $7.5 \mathrm{Ha}$ was selected from the analysis of aerial photographs and previous visits. The experimental design consisted of weekly sampling from February 2009 to June 2013. A linear transect in the center of the forest land of $1030 \mathrm{~m}$ was performed, with a bandwidth of $5 \mathrm{~m}$, covering an area recommended for this kind of survey [44]. It was a qualitative study, assessing the presence or absence of epigeous Ascomycota and Basidiomycota species with medium or large fruit bodies. The collected specimens were identified at the Institute for Agrobiotechnology Research (CIALE, University of Salamanca) using classical techniques in mycology, analyzing both macroscopic and microscopic characters and using different chemical reactions [21]. The different taxa and groups were identified and classified using general and specific literature, while CABI Index Fungorum [45] and Kirk et al. [46] were referenced mainly for the nomenclature.

Species collected in other parts of the La Orbada forest by the University of Salamanca were also used to accomplish biodiversity tests.

\subsection{Diversity Analysis}

\subsubsection{Alpha and Beta Diversity}

The most direct measure of biodiversity is richness [47,48], so we assessed the fungal biodiversity of La Orbada forest based on the species richness recorded. Alpha diversity was the number of species obtained in transects. In spite of the lack of botanic homogeneity characterizing Mediterranean ecosystems [49], five Mediterranean communities dominated by Quercus spp. with a known macrofungal diversity (Figure 1) were selected to obtain Beta diversity: 
Campanarios de Azaba Biological Reserve: Located in central-western Spain, it presents the traditional agrosilvopastoral system known as "dehesa" (in Spanish) or "montado" (in Portuguese). In this area, there is a predominance of holm oaks mixed with Pyrenean oaks (Quercus pyrenaica Willd.) and meadows of different types and compositions. The study of macrofungal diversity was developed between 2009 and 2012 [37].

Foros: A "montado" dominated by cork oak (Quercus suber L.) with holm oaks, located in central Portugal (western Iberian Peninsula). Fungal fruiting bodies were collected between 2003-2006 [33].

Peloponnese: A study made in the southern part of the Peloponnese (southern Greece), in deciduous forests of Quercus spp., mainly Italian oak (Quercus frainetto Ten.) and downy oak (Quercus humilis Mill.), in the 1996-2001 period [19].

Fango: Located in Corsica (France). It is a mature holm oak forest with many large trees and a large shrub cover of $7 \mathrm{~m}$ high. Although the vegetation appears to be similar to La Orbada forest, there are other woody species capable of associating with ectomycorrhizal fungi such as strawberry tree (Arbutus unedo L.). This work was developed between 1999 and 2002 [20].

Collestrada: A study carried out during 2011 in the Collestrada forest (Central Italy). The vegetation is heterogeneous, with several species of Quercus spp., European hornbeam (Carpinus betulus L.) and plantations of stone pine (Pinus pinea L.) and maritime pine (Pinus pinaster Aiton) [35].

We compared ecosystems using the Sørensen Similarity Index (Is), which allowed us to describe the spatial differentiation and differences in species richness between these communities [28]. For this analysis, collections determined at species level or synonymized after publication were not taken into account.

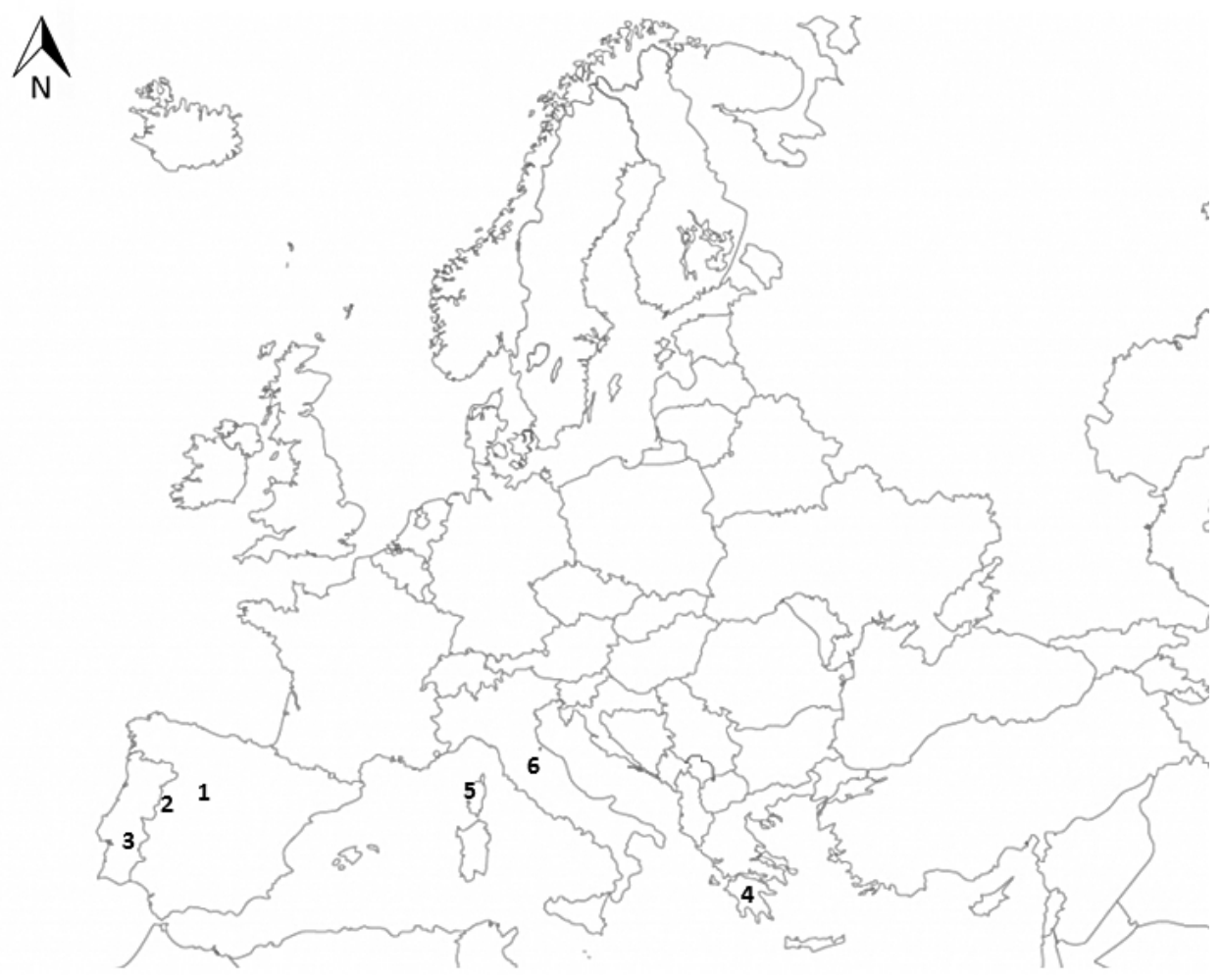

Figure 1. Location of Mediterranean habitats used in the analysis of Alpha and Beta Diversity. 1: La Orbada Forest (CW, Spain), 2: Campanarios de Azaba Biological Reserve (CW, Spain), 3: Foros (C, Portugal), 4: Peloponnese (S, Greece), 5: Fango forest (Corsica, France), 6: Collestrada forest (C, Italy). 


\subsubsection{Non-Parametric Estimators}

Non-parametric estimators are based on the study of rare species and allow us to estimate new species numbers from the ratios of species already detected in the samples. There are two types of non-parametric estimators: based on abundance and incidence models [50]. We used estimators based on incidence models because it was a presenceabsence study. The incidence model considers the number of samples in which each species is present. Four non-parametric estimators were applied to the dataset: Jacknife 1, Jacknife 2, Chao 2 and Incidence-based Coverage Estimator (ICE) [51]. Estimations were made using EstimateS vers. 9.0 [52], and the results of the random rearrangements were exported to a Microsoft Office Excel file, where the bias was calculated and the graphs were developed. Therefore, we performed a rarefaction curve fitted, by extrapolation, to the asymptotic species accumulation functions. This resulted in smoothed curves calculated with nonparametric estimators that allowed us to estimate the real richness of the species. The smooth richness accumulation curve, S(est), is a sampling-based rarefaction curve, which estimates the statistical expectation of the number of species observed when resampling over the total number of sampling units at each site with increasing efforts [53]. The upper and lower limits of the $95 \%$ confidence intervals for S(est) were also plotted. Finally, we determined the real richness by fitting the cumulative richness curve to one of the species accumulation models and extrapolating for an infinite sampling effort [54]. Chao 2 estimates the presence-absence data of a species in a given sample, i.e., whether the species is present and how many times it is present in a given sample [55].

\subsection{Statistical Analysis}

Principal Coordinate Analysis (PCA), a multivariate ordination analysis, was performed using a similarity coefficient that took into account the binary character of the data (Sørensen coefficient). The PCA identifies the points in a weekly scatter plot with the combination of both variables. January 2009 is not represented because there is no data, nor other combinations in which no species were found in the corresponding weeks.

The analyses were performed with $\mathrm{R}$ (R Core Team 2016) using the vegan packages [56] and MultBiplotR [57]. In the graphical representation of PCA analyses, the dimensions obtained can be interpreted as hypothetical (environmental) gradients that adequately capture the structure of the data [58]. Two weeks of sampling will appear next when their species composition is similar and, indirectly, when the environmental conditions necessary for the development of fungal fruiting bodies are the same.

\section{Results}

In the four years studied, 173 different taxa were identified. If the number of species collected weekly is grouped by months and accumulated by years (Figure 2), greater fungal fruiting in late autumn and early winter (November, December and January) was observed, followed by smaller and shorter fruiting in early spring (April). Species were collected during all months of the year.

The most abundant species (collected in more than 40 weeks) were Leccinellum lepidum H. Bouchet ex Essette) Bresinsky \& Manfr. Binder, Infundibulicybe gibba (Pers.) Harmaja (=Clitocybe gibba (Pers.) P. Kumm.), Laccaria laccata (Scop.) Cooke, Lepista nuda (Bull.) Cooke and Russula fragilis Fr. Figure 3 shows the species collected in at least 18 samplings, with annual fruiting during autumn-winter and extensive collection over a period of several weeks. 


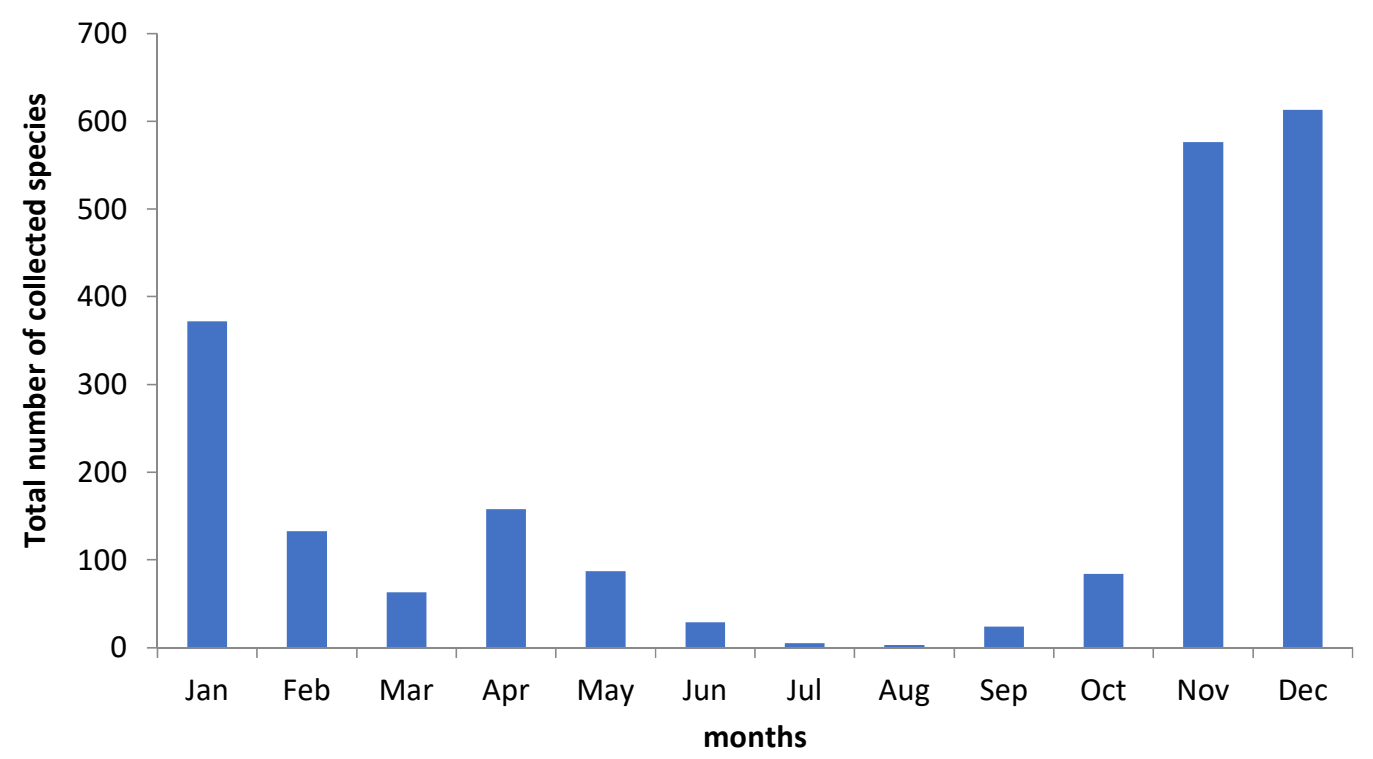

Figure 2. Total number of collected species accumulated by months.

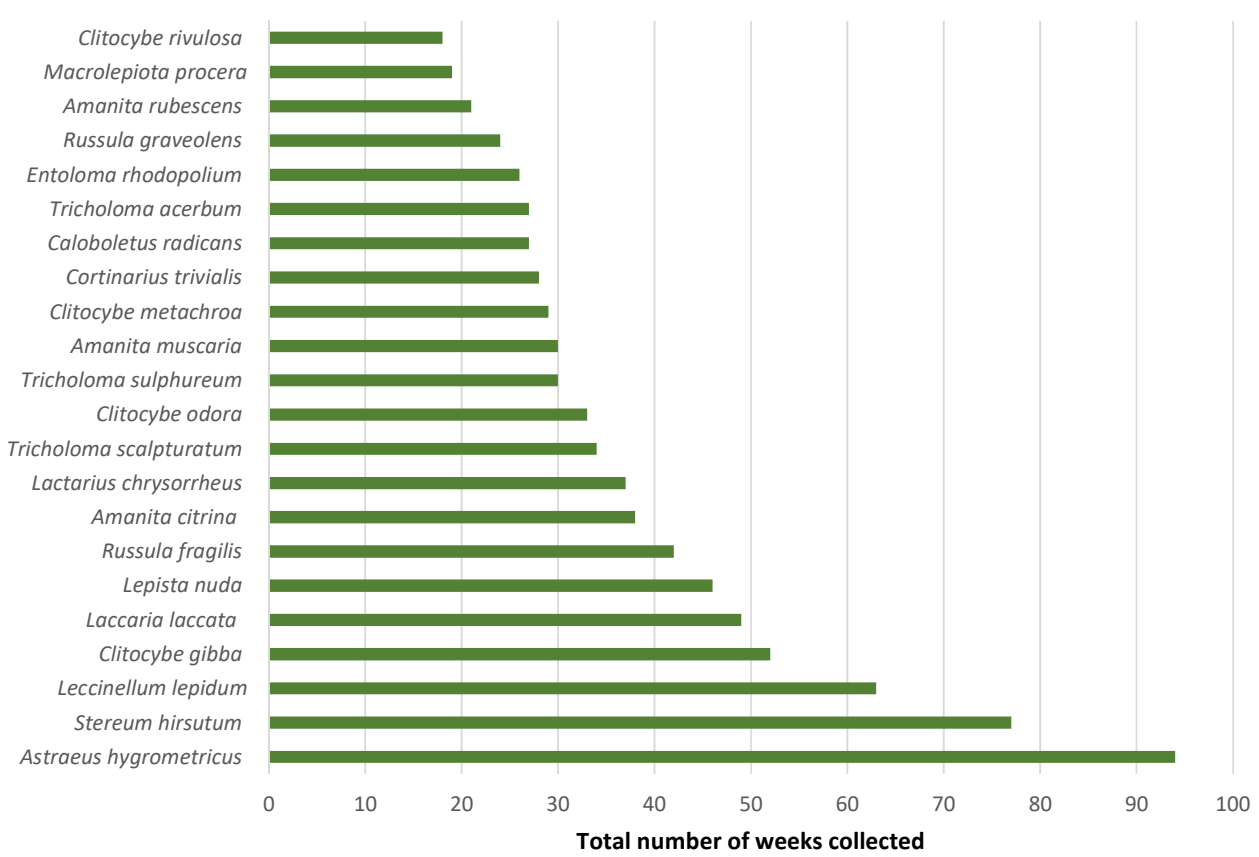

Figure 3. Number of weeks of collection for the most abundant species.

The species collected in the months of July and August were all mycorrhizal: Boletus aereus Bull., Suillellus queletii (Schulzer) Vizzini, Simonini \& Gelardi, Caloboletus radicans (Pers.) Vizzini, Leccinellum lepidum, Amanita rubescens Pers., Russula pectinatoides Peck. and Russula heterophylla (Fr.) Fr., with Caloboletus radicans being the most abundant, collected for 27 weeks.

Macrofungal species richness (S), total number of species collected, and Sørensen similarity indexes (Is), obtained by comparing the La Orbada forest (189 species) with other Mediterranean ecosystems dominated by Quercus spp., are shown in Table 1. The number of species identified in the study area was higher than those recorded in Foros, Campanarios de Azaba Biological Reserve and Collestrada (133 species), similar to southern Peloponnese and lower than those collected in Fango forest. Similarity rates were low. 
Table 1. Diversity parameters between total collections in La Orbada forest (189 species) and other Mediterranean ecosystems dominated by Quercus species.

\begin{tabular}{cccc}
\hline Sites & S & SC & Is \\
\hline Campanarios de Azaba BR (Spain) & 148 & 55 & 0.32 \\
Foros “montado" (Portugal) & 172 & 60 & 0.33 \\
Fango forest (Corcega) & 234 & 44 & 0.24 \\
Collestrada (Italy) & 133 & 41 & 0.26 \\
Peloponnese (Greece) & 197 & 42 & 0.22 \\
\hline
\end{tabular}

S: Species richness; SC: Species in common; Is: Sørensen similarity index.

Figure 4 shows the total number of species collected per season, displaying also an annual fluctuation of the fungal fruiting with great interannual variation. It should be noted that for the year 2013 data only appear until spring because the study ended in June 2013. The macrofungal fruiting bodies were collected during the four seasons, with a maximum production period that begins in autumn and does not end until spring. The season with the highest number of species was autumn, except in the year 2011, where it took place in winter.

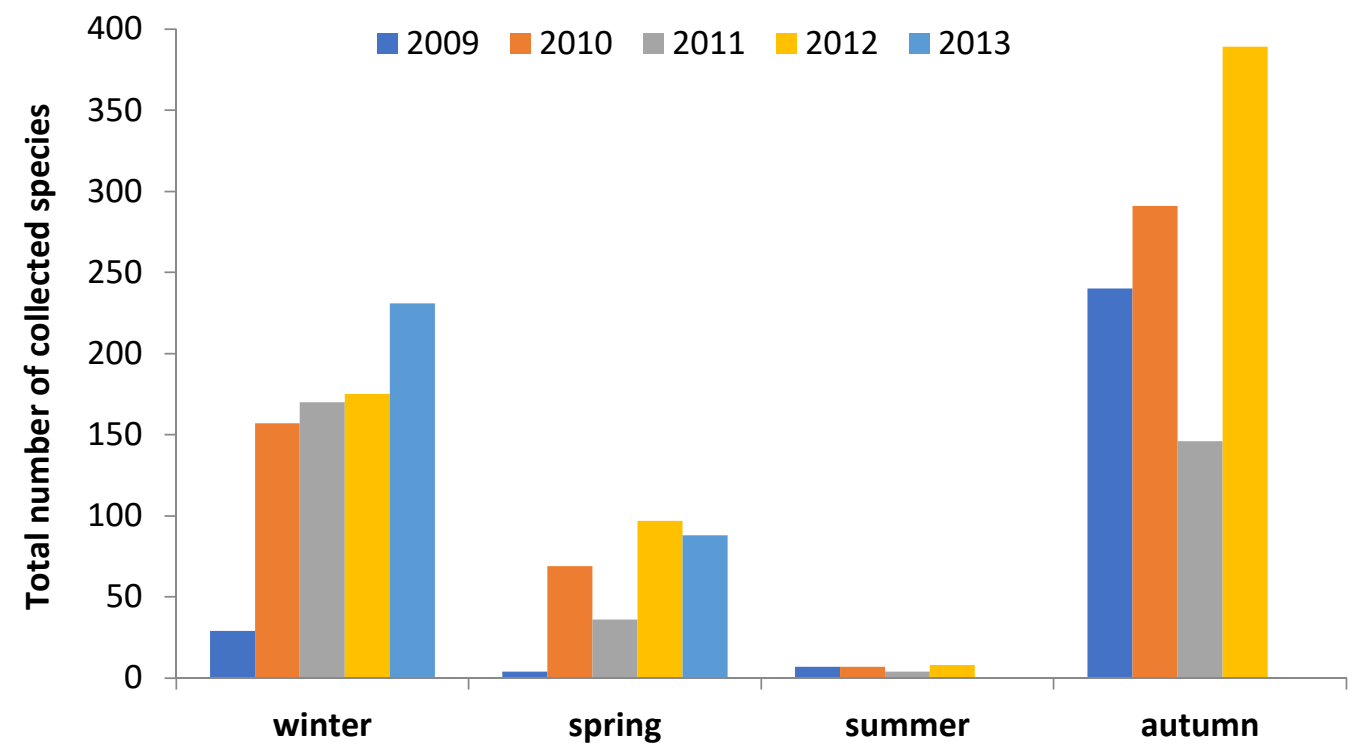

Figure 4. Total number of species collected by seasons.

The greatest diversity of species collected during the study period occurred in the months of December and November, with an average of 153 and 144 species identified, respectively. January also recorded a high macrofungal diversity, with 93 species on average, although the remaining winter months showed a lower number of species, with 27 and 13 species on average in February and March, respectively (Figure 5). This decline continued during the following months, except in the month of April with a slight average increase of 32 species for all the years analyzed. In some months of July and August in the 2009-2012 period, no species were found. Likewise, a small increase in fungal diversity was observed in late summer and early autumn, with 21 species on average collected in October of the 2009-2012 period, a similar average number for the month of May (17 species). 


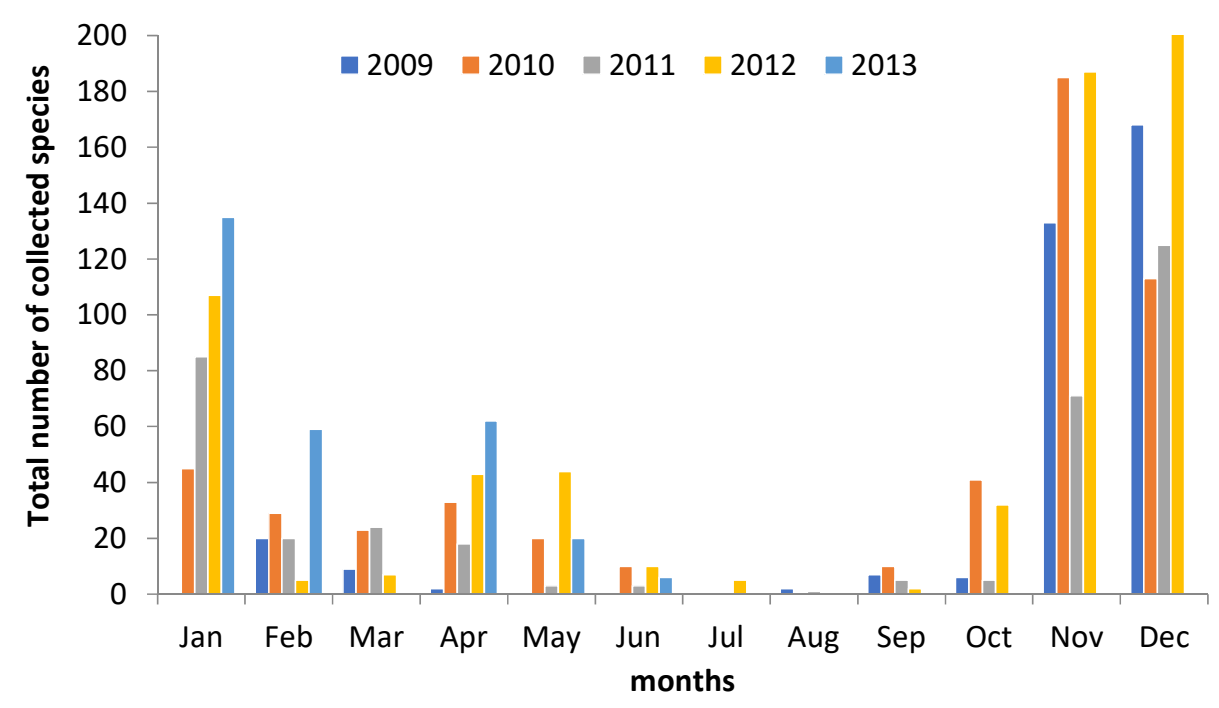

Figure 5. Total number of species collected per years and months.

In any case, the interannual variation indicated that fructification took place throughout the year with higher production in December, a decrease throughout the winter, a slight increase in April and very low average diversity values in the summer months (six in June and September, one in July and August, respectively).

A weekly analysis of fungal diversity in the transition months between autumn and winter (December and January) indicates that the last weeks of autumn (second and third week of December) had a greater variety of fruiting bodies, except in 2009 where it took place in the first week of December (Figure 6). Subsequently, the number of species collected decreased in early winter (last week of December and first two weeks of January) but remained more or less stable for one month.

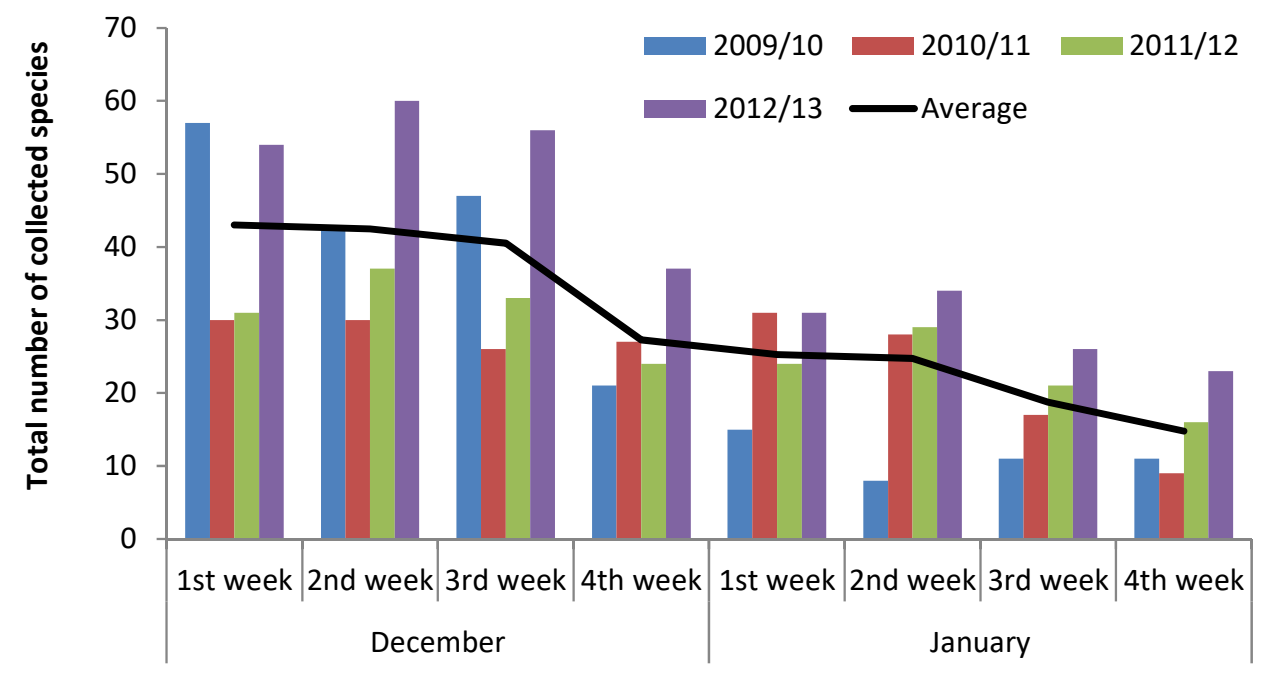

Figure 6. Total number of collections per week in December and January for the four years of survey.

An analysis of the number of taxa identified weekly in the La Orbada forest (Figure 7) indicated a first spring with low diversity, which increased exponentially in autumn 2009. In subsequent years, there was the same seasonal behavior on a smaller scale, increasing in the spring and autumn periods and remaining stable the rest of the year. This stability did not imply that there were no slight increases in diversity as the amount of sampling progressed, although at the end of the study (June 2013), there did not seem to be a plateau in the number of taxa collected. The number of new species collected during the first 
12 months of the study was 110, 33 new species were collected in the 2010/2011 period (143), 13 in the 2011/2012 period (156) and 17 in the last period.

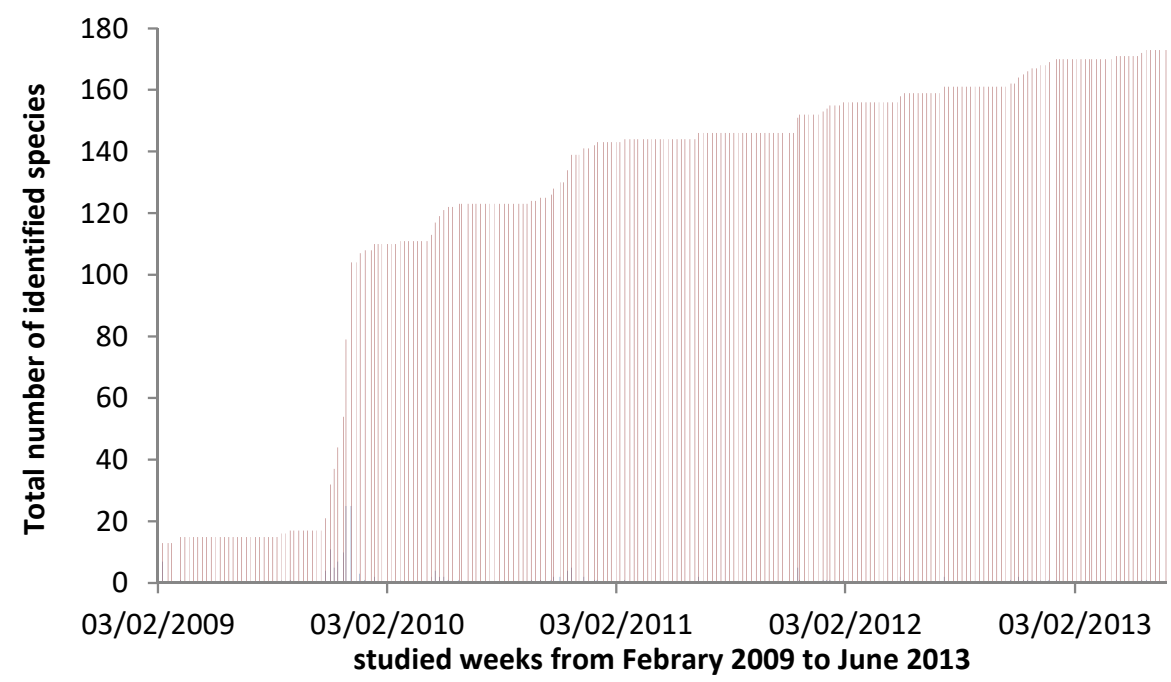

Figure 7. New species (accumulated) identified during the studied period in La Orbada forest by weeks of sampling.

The smooth richness accumulation curve gradually lost slope as the number of sample units increased, clearly tending towards an asymptote (Figure 8a). The statistical expectation of the number of species observed at the end of the work was close to the asymptotic richness, exceeding the logarithmic phase of the curve, for 229 transects it was 172, with a confidence interval between 162 and 182 species.

Non-parametric estimators smoothly approximate the asymptotic richness with increasing sampling efforts. Some of them were above the observed richness values, underestimating the asymptotic richness and producing a positive bias (Figure 8b). The most efficient species accumulation models were ICE, $87.60 \%$, and Chao $2,85.14 \%$.

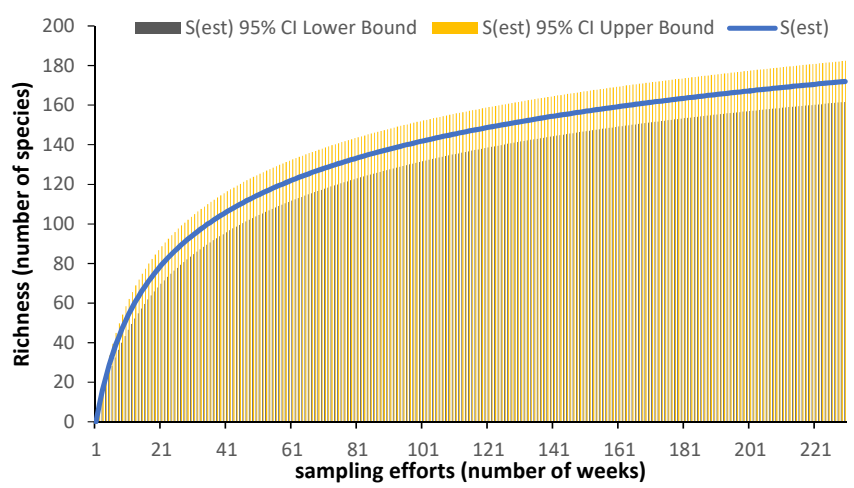

(a)

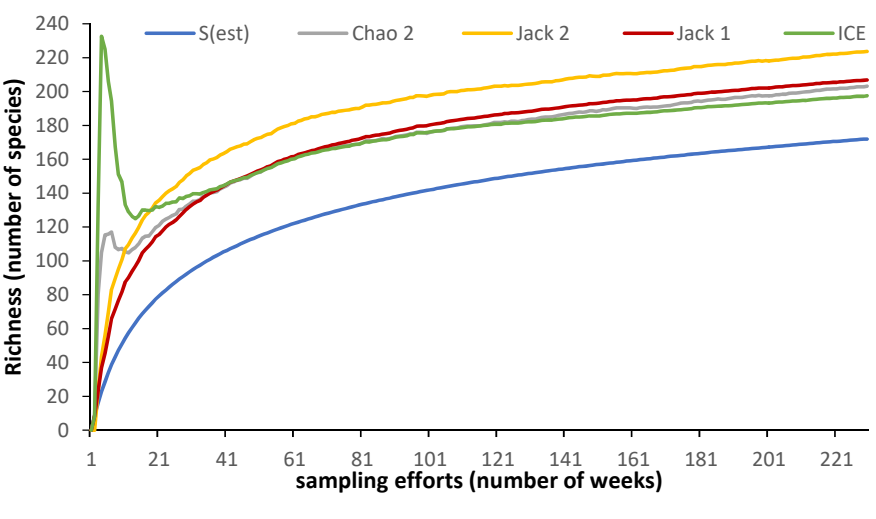

(b)

Figure 8. (a) Species rarefaction curve S(est), Upper and lower bounds of the $95 \%$ confidence interval. (b) Smooth richness accumulation curves for the non-parametric estimators ICE, Chao 2, Jack 1, Jack 2.

In the graphic representation of the weeks studied by means of a Principal Coordinate Analysis (PCA), four patterns of behavior were observed, four groups of weeks isolated and with very little similarity among them and among the species collected in each of those weeks (Figure 9). Group A, located in the lower left corner, was formed by a large number of weeks with great similarity (short distances); two subgroups can be distinguished, one 
located at the upper part, around week 154 that would be the centroid, and another in the lower part, around centroid week 204. Group B, located in the upper region of the figure, was less numerous than the previous one, and it was composed of a smaller number of weeks and was more distant from each other than the previous one, displaying also less homogeneity in the species that integrate them. This group appeared to be divided into two subgroups organized around different centroids, a left subgroup (week 174) and a right subgroup (week 167). The third group, group C, appears in the central right, and was formed by a small number of weeks quite dispersed and consequently different in their composition. Finally, group D, located at the bottom right, was made up of very few weeks, and it was very separated from the rest of the groups.

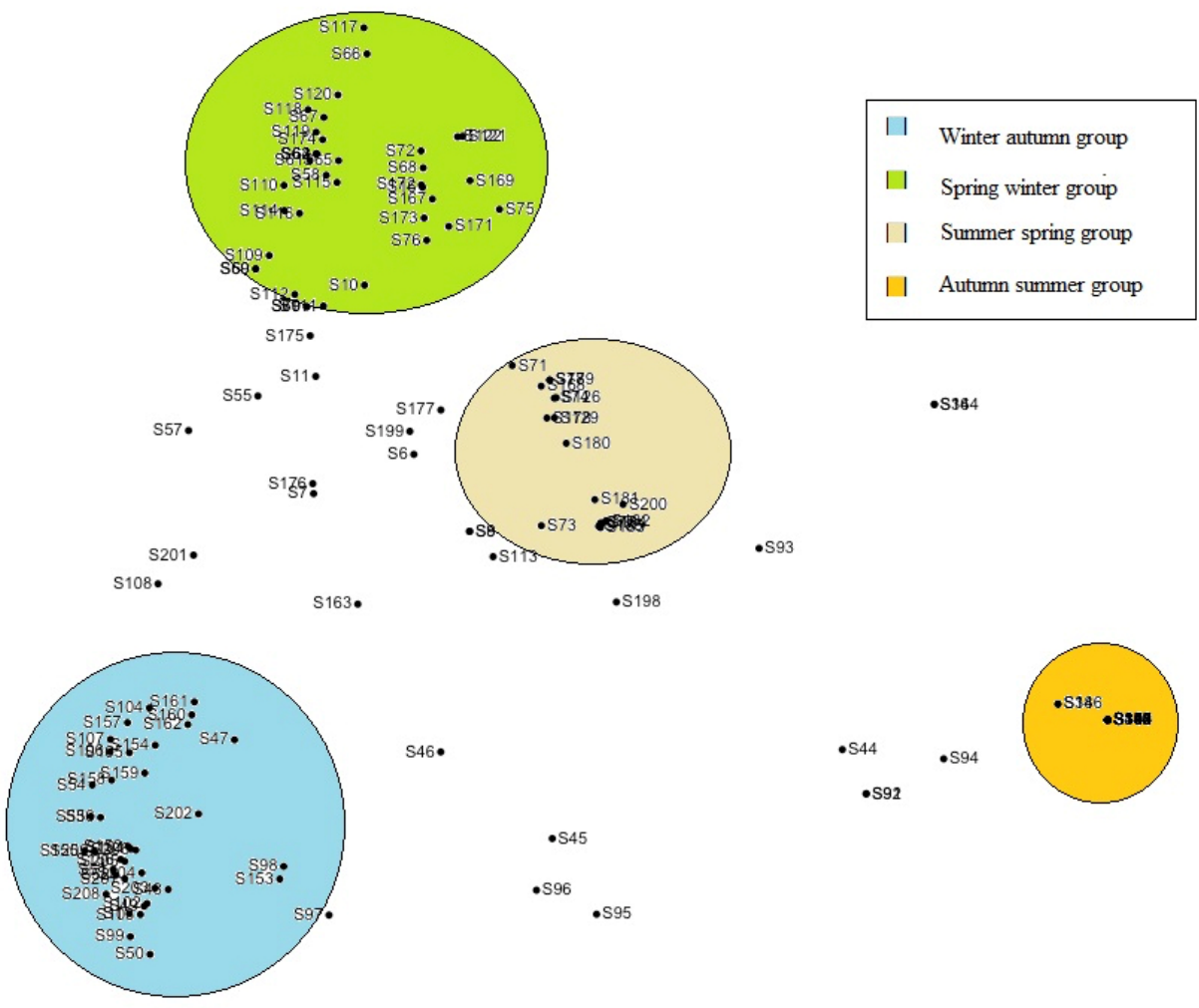

Figure 9. Groups identified in the PCA by week. The points (S) indicate the weeks of sampling.

Figure 10 presents the results of applying the PCA to macrofungal diversity by month in the period 2009-2012. January 2009 was not included in the analysis because no data were available; we also excluded February 2013 for better comparison among full years. It was observed that the four groups described in Figure 9 mainly belonged to pairs of months that were not dispersed and were constant over the years studied. The months of November and December had the least number of differences between them and in the set of years studied. Both months covered the weeks of group A, while the month of January presented a significant correlation with the upper subgroup of group A. March and April corresponded to group B; May and June to group C; and August and September to group D. February and October were the months that differed the most over the years, meaning that the species identified in these months varied from year to year. For example, February 2009 behaved similarly to May and June of that year, while the same month in 2010 and 2011 displayed more similarities with March and April of both years. 


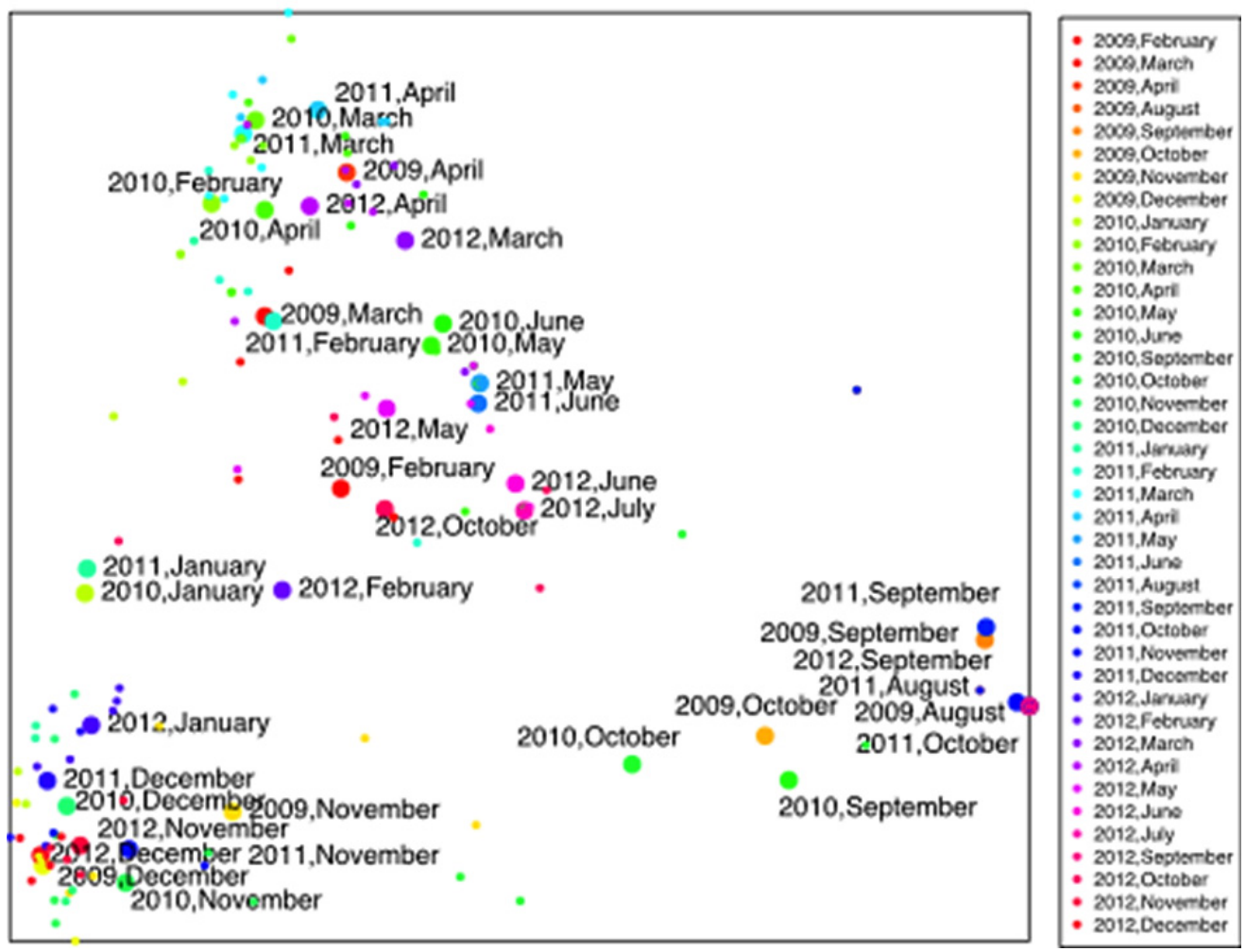

Figure 10. PCA for the months in the 2009-2012 period. The points correspond to the year and month.

\section{Discussion}

\subsection{Macrofungal Fructification}

The monthly distribution indicated that fungal fructifications did not disappear throughout the year, although the number of species collected in the different months was very different. In addition, a high macrofungal diversity was observed during the months of January and February, and the monthly fruiting for years was very variable. This difference was observed in the spring of 2009, when the number of species collected was significantly lower than in the rest of the years during the same season.

The similarity indices (Is) obtained were low, with none greater than 0.33 , which could indicate a distancing of populations among the Mediterranean ecosystems compared, as result of latitudinal variation in fungal diversity [59] or the effect of rainfall $[8,60,61]$. However, two other factors could be taken into account to explain these differences. On the one hand, this could be explained by the plant variability that characterizes Mediterranean areas, housing almost $20 \%$ of the vascular plants when they occupy just under $5 \%$ of the land surface [49], and that in the case of the ecosystems compared, there were several vegetation units as opposed to the almost exclusive vegetation unit in the Orbada forest. On the other hand, the different prospecting methodologies used should not be ignored. In the forest of La Orbada and Collestrada, specimens were collected throughout the year; in Foros, it was carried out from September to December; in Campanarios de Azaba Biological Reserve, during the autumn and spring seasons; in the southern part of the Peloponnese, there were no collections during summer, and Fango forest was prospected from 15th September to 15th March. The number of years employed also varied: one in Collestrada forest, three in Campanarios de Azaba Biological Reserve and in Fango forest, four in Foros and five in southern Peloponnese and in La Orbada forest. 
Many factors could influence fungal fruiting in a given ecosystem that cannot be controlled, such as plant biodiversity [49], climatic conditions [62], latitude [59] or pollution [63], among others. All this could make it difficult to compare results among different studies on macrofungal fruiting in Mediterranean climates. However, we consider it essential to try to minimize the biases due to heterogeneous sampling methodologies in intensity and duration. At this point, studies that are more or less exhaustive in time and frequency, with different numbers of qualified personnel or more or less precise identifications, could make it impossible to compare richness indexes in similar ecosystems [41].

\subsection{Climatic and Meteorological Factors}

The temporal evolution of the main meteorological variables in the study area displayed a clearly positive trend of annual temperatures (mean, maximum and minimum), with a negative trend, not statistically significant, in rainfall [43]. In addition, climate models predict an increase in average temperature between $2.2^{\circ} \mathrm{C}$ and $5.1^{\circ} \mathrm{C}$, with a potential decrease of $4 \%-27 \%$ in annual rainfall during the 21 st century, as well as dramatic changes in the distribution of the rains in the Mediterranean basin [23]. The period of highest fungal production during the study comprised the months of September to May and it was not limited to autumn, resulting in a delay to the winter months that joined the traditional periods of autumn and spring. This fact could be explained by climate change that, as well as delaying the appearance of ectomycorrhizal fruiting bodies in forest areas dominated by deciduous trees [24,64], could delay the fructification towards the first weeks of winter in forests with holm oak dominance $[25,65]$. On the other hand, the PCA results for the analyzed weeks showed four separated groups with a greater similarity of species, which seemed to indicate that the formation of carpophores was not restricted to a certain time of the year, but neither could it be included in a single fruiting period. If the sampling season in our study had been restricted to the autumn season, $16 \%$ of the species collected would not have been recorded, a bias that could influence the results of surveys trying to describe macrofungal diversity in Mediterranean ecosystems.

Global climate change is generating debate about its impact on the ecosystem biodiversity in the near future [66]. In particular, the Mediterranean region could be especially vulnerable, with the extinction of more than 2000 plant species [67] and negative consequences on the structure, dynamics and functioning of forests $[68,69]$. Therefore, populations will have to adapt to and compete in new environmental conditions, and the response of the fungal communities will be part of that ecological competition [70,71], producing changes in the composition of the species in the ectomycorrhizal communities [8,72]. For this reason, taxa collected in the summer season, although not important from a quantitative point of view, should be of great importance as they are able to fructify in the most adverse weather conditions, and potentially, they are the best adapted to some conditions that could be extended throughout the year. A methodology that does not include the most adverse months could carry a qualitatively significant bias by not paying attention to these taxa and overlooking the possible response of a dynamic system to variable conditions and disturbances, a fundamental aspect for its analysis. The presence of a late-fruiting pattern could indicate that a method that attempted to estimate $75 \%$ of the biodiversity by concentrating the sampling effort, would have to include winter and autumn (Figure 11) but it could still omit the species that fruit in spring and summer. All this could lead to the loss of information on the response of fungal communities to climate change in Mediterranean forest ecosystems. 


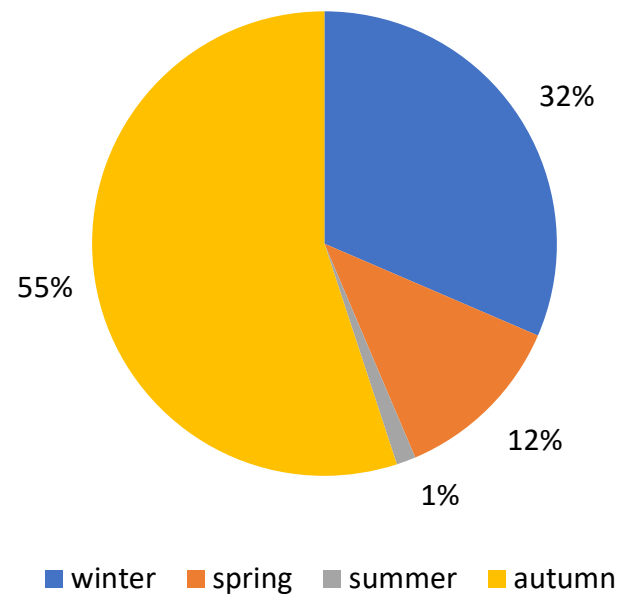

Figure 11. Average species collected by seasons. Percentages (\%) over the studied period.

\subsection{Macrofungal Lifestyles}

The grouping of identified taxa by their form of nutrition (Figure 12) can contribute to our understanding of how symbiotic fungi, saprophytes and parasites develop their life cycle, and to a better understanding of their ecological functions and their impact on plant communities [73]. The saprophytic species were more represented in winter and less in summer, disappearing in July and August (all the species collected were mycorrhizal), which seemed to indicate that macrofungal saprophytes were more sensitive to adverse summer conditions and perhaps to climate change. The mycelium of saprophytic taxa could be more affected by atmospheric changes, since they are more superficial (in humus and litter) than symbionts $[36,74]$. The exclusive appearance of symbiotic species could be related to large-scale disturbances in ecosystems, which could lead to collapse or increase of the overall density of the vegetation $[75,76]$ and the associated fungal community. Similarly, the increase of $\mathrm{CO}_{2}$ as a result of global warming leads to an increase in the growth of plants $[77,78]$ and subsequently the mycorrhizal symbionts of trees and shrubs $[79,80]$. The changes in the mycorrhizal community are the basis for the carbon demands of fungi and the variation of carbon costs for the host in a changing environment [70,81]. On the other hand, variations in nitrogen levels, important in the competitive relationships between plants and fungi, could affect the fungal composition $[82,83]$.

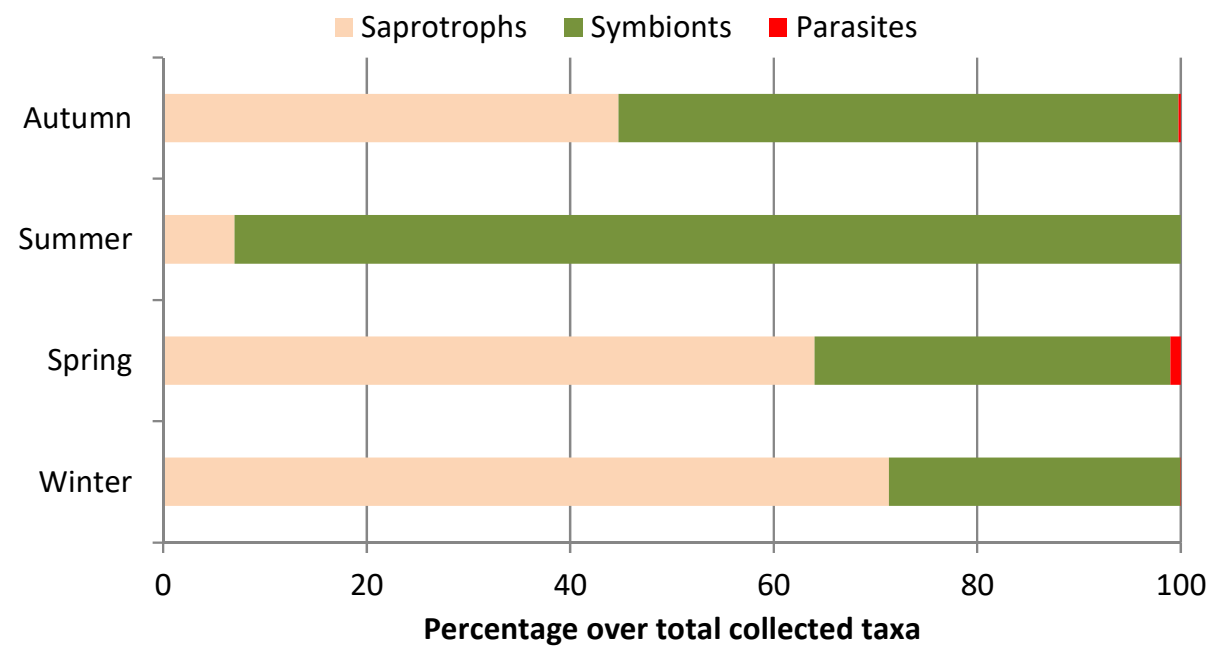

Figure 12. Percentage of total fungal collections sorted by season and form of nutrition. 


\subsection{Viable Methodology in Field Studies}

Field methodology usually only includes macrofungi [84], as they form more easily observable spore-bearing structures than microfungi [85]. Furthermore, microfungi are rarely considered in relation to conservation [86]. However, some studies suggest that most fungi could be termed "microfungi" and many are probably rare and threatened [87]. At this point, the valuable contribution of molecular techniques should be highlighted, not only for the assessment of fungal diversity in different substrates of a given ecosystem [88,89], but also in the evaluation of fungal fruiting [90]. In any case, the importance of field studies to assess macrofungal diversity and evaluate their fruiting remains evident [91], not only because of their lower methodological and economic cost but also because of possible limitations in delimitations at the specific level with DNA sequences [92].

The estimation of the macrofungal diversity in holm oak-dominated Mediterranean ecosystems may seem simple due to the low plant diversity of these formations with respect to other Mediterranean forests $[93,94]$ and the low specific fungal diversity in fruiting bodies, in which three fungal species may account for more than $50 \%$ of the carpophores found $[95,96]$. However, the type of vegetation has a low influence on the mechanisms that regulate fungal fruiting $[36,97]$ and the fungal diversity does not follow the same latitudinal distribution pattern as other organisms. In fact, it seems that fungal diversity depends on the type of vegetation and the composition of the forest, correlating inversely with plant diversity due to a high level of fungal speciation [59]. For this reason, to the great fungal diversity expected in Mediterranean forest systems, we must add other problems when establishing a viable study methodology: the large number of known fungal taxa, the intraspecific variation, the inconstant appearance of fruiting bodies over the years, and the need for specialized personnel in taxonomic determination [41]. This could include another problem that this study highlighted: the need to prospect throughout the year and over a period of several years. Viable fungal diversity studies cannot avoid having biases, but they should be minimized if reliable results are to be obtained, with constant collection throughout the year being one of the most important factors to achieve this goal. This type of sampling would make it possible to include a number of prevalent species, very abundant species and species of annual appearance that have been successful in competing for available habitats, and with greater ecological plasticity than a random distribution would indicate [17]. In the same way, it would also allow for the inclusion of saprophytic leaf and soil indicator species for each plant type, with high fidelity but relatively low abundance [98], a series of early-stage mycorrhizal species [99] and a last series that would include the species that could fructify in the most adverse weather conditions.

There is no doubt that the more years a study lasts, the more complete it will be, but doing such long studies is too expensive. The rarefaction curve obtained did not reach equilibrium and the number of new species collected during the last year is high, but the exponential phase has been overcome and it approaches the plateau phase, with a percentage of variability that has decreased over the years. Some studies have shown that the collection of specimens depends on the intensity of sampling in the same season or year, or on the number of samples in different seasons and years [100,101]. In our study, we chose weekly sampling in order to better characterize the diversity of some groups that seem to be favored by continuous sampling, such as agarics [86]. In the form of a summary by year of sampling, in the first two years $83 \%$ of the total species were collected in La Orbada forest reaching $90 \%$ during the third year (Figure 13). Alpha and beta diversity obtained for La Orbada forest and other Mediterranean ecosystems dominated by Quercus sp. gave an approximate insight into fungal richness. On the other hand, the exhaustive samples of 229 weeks allowed the performance of the non-parametric estimators to be assessed even if they underestimated real richness [48,102]. The Chao 2 estimator appeared to be the best adapted to the transects of our study, possibly because it studies rare species and allows species to be estimated from incidence ratios [53]. The estimate for our field work was 203 species, compared to 173 collected. The differences in the asymptotic estimates 
were small, $85.15 \%$ of efficiency, so we believe that the obtained inventory could optimally reflect fungal diversity.

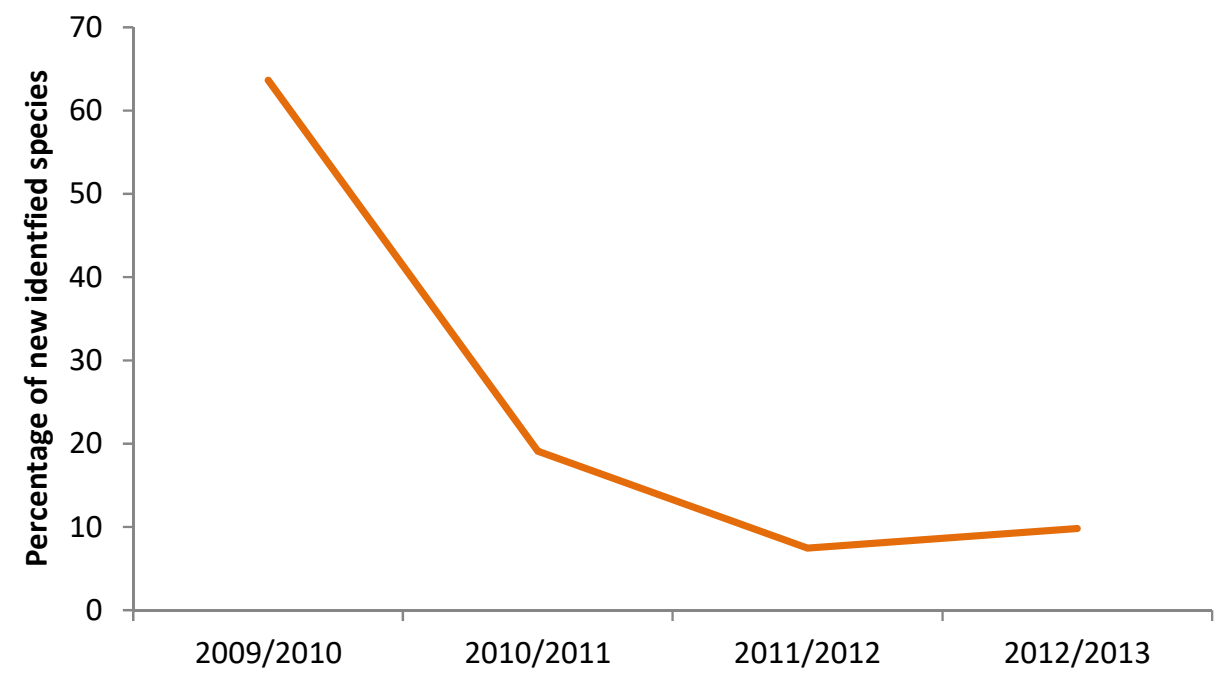

Figure 13. Total percentage of new identified species per collection years from February 2009 to June 2013.

Taking into account that fruiting species do not reflect the real fungal diversity of the mycorrhizal community [62], the larger inter-annual variation of species, and that is not possible to collect fruiting bodies of all fungal species present in an environment [17], we considered Chao 2 efficiency values. We estimated the minimum collection time to obtain $75 \%$ of the species was 133 weeks - two and a half years. With two years smooth richness accumulation curve reaching 144 species, we would obtain an efficiency of $70.60 \%$, with a confidence interval between $65.95 \%$ and $75.79 \%$. Data obtained over two years could allow us to assess the fungal diversity of a Mediterranean ecosystem with holm oak dominance and to compare results by collecting a high percentage of species. However, many of the questions concerning the estimation of diversity may remain unanswered, so we think it is necessary to carry out a greater number of studies in these environments that could contribute to solving them.

In any case, we agree with Cannon [103] and Hyde [104] that rapid initial studies developed by unqualified personnel are also important to allow an approach to diversity and a comparison among different ecosystems. Prior knowledge of the prevalent species in similar ecosystems, the identification at the genus level of the species collected, the consideration of their form of nutrition and the qualitative proportion among them could be a good starting point.

A suitable sampling method for macrofungi in Mediterranean ecosystems should pay particular attention to summer fruiting and the displacement of fungal fruiting towards winter. The monitoring of organisms in their own environment and their changes are essential to achieving a true renewal of science [105]. We believe that sampling carried out during a minimum period of two years, periodically and regularly throughout the year, could take into account the possible variations in fructification as a consequence of the meteorological factors, and could make it possible to know the fungal diversity of the studied forest ecosystem.

Author Contributions: Conceptualization, A.F.R., P.G.J., D.R.d.1.C. and J.S.S.; methodology, A.F.R., D.R.d.I.C. and J.L.V.V.; software, J.L.V.V. and A.F.R.; validation, J.L.V.V., A.F.R., S.S.D. and J.S.S.; formal analysis, A.F.R., D.R.d.l.C. and J.S.S.; investigation, A.F.R., D.R.d.l.C., P.G.J. and J.S.S.; resources, J.S.S., D.R.d.l.C. and A.F.R.; data curation, A.F.R. and P.G.J.; writing-original draft preparation, A.F.R., D.R.d.l.C. and J.S.S.; writing-review and editing, A.F.R., S.S.D., D.R.d.l.C., P.G.J. and J.S.S.; visualization, A.F.R., D.R.d.I.C. and J.L.V.V.; supervision, A.F.R., P.G.J. and J.S.S.; project administration, A.F.R., 
P.G.J., D.R.d.l.C. and J.S.S.; funding acquisition, A.F.R., D.R.d.l.C. and J.S.S. All authors have read and agreed to the published version of the manuscript.

Funding: This research received no external funding.

Data Availability Statement: Not applicable.

Acknowledgments: The authors would like to thank Sergio Pérez Gorjón for his advice on several identifications.

Conflicts of Interest: The authors declare no conflict of interest.

\section{References}

1. Taylor, D.L.; Hollingsworth, T.N.; McFarland, J.W.; Lennon, N.J.; Nusbaum, C.; Ruess, R.W. A first comprehensive census of fungi in soil reveals both hyperdiversity and fine-scale niche partitioning. Ecol. Monogr. 2014, 84, 3-20. [CrossRef]

2. Wijayawardene, N.N.; Hyde, K.D.; Al-Ani, L.K.; Tedersoo, L.; Haelewaters, D.; Rajeshkumar, K.C.; Zhao, R.L.; Aptroot, A.; Leontyev, D.V.; Saxena, R.K.; et al. Outline of Fungi and fungus-like taxa. Mycosphere 2020, 11, 1060-1456. [CrossRef]

3. Perotto, S.; Angelini, P.; Bianciotto, V.; Bonfante, P.; Girlanda, M.; Kull, T. Interaction of fungi with other organisms. Plant Biosyst. 2013, 147, 208-218. [CrossRef]

4. Cannon, P.F.; Sutton, B.C. Microfungi on wood and plant debris. In Biodiversity of Fungi; Mueller, G.M., Bills, G.F., Foster, M.S., Eds.; Elsevier Academic Press: Cambridge, MA, USA, 2004; pp. 217-239.

5. Rubino, D.L.; McCarthy, B.C. Composition and ecology of macrofungal and myxomycete communities on oak woody debris in a mixed-oak forest of Ohio. Can. J. For. Res. 2003, 33, 2151-2163. [CrossRef]

6. Landi, M.; Salerni, E.; Ambrosio, E.; D’Aguanno, M.; Nucci, A.; Saveri, C.; Perini, C.; Angiolini, C. Concordance between vascular plant and macrofungal community composition in broadleaf deciduous forest in central Italy. Iforest 2015, 8, 279-286. [CrossRef]

7. Kutszegi, G.; Siller, I.; Dima, B.; Merényi, Z.; Varga, T.; Takács, K.; Turcsányi, G.; Bidló, A.; Ódor, P. Revealing hidden drivers of macrofungal species richness by analyzing fungal guilds in temperate forests, West Hungary. Community Ecol. 2021, 22, 13-28. [CrossRef]

8. Richard, F.; Roy, M.; Shahin, O.; Sthultz, C.; Duchemin, M.; Joffre, R.; Selosse, M.A. Ectomycorrhizal communities in a Mediterranean forest ecosystem dominated by Quercus ilex: Seasonal dynamics and response to drought in the surface organic horizon. Ann. For. Sci. 2011, 68, 57-68. [CrossRef]

9. Vogiatzakis, I.N.; Mannion, A.M.; Griffiths, G.H. Mediterranean ecosystems: Problems and tools for conservation. Prog. Phys. Geogr. 2006, 30, 175-200. [CrossRef]

10. Biasi, R.; Brunori, E.; Ferrara, C.; Salvati, L. Towards sustainable rural landscapes? a multivariate analysis of the structure of traditional tree cropping systems along a human pressure gradient in a mediterranean region. Agrofor. Syst. 2017, 91, 1199-1217. [CrossRef]

11. Bazzato, E.; Lallai, E.; Serra, E.; Mellis, M.T.; Marignani, M. Key role of small woodlots outside forest in a Mediterranean fragmented landscape. For. Ecol. Manag. 2021, 496, 119389. [CrossRef]

12. Hidalgo, P.J.; Hernández, H.; Sánchez-Almendro, A.J.; López-Tirado, J.; Vessella, F.; Porras, R. Fragmentation and Connectitivy of Island Forests in Agricultural Mediterranean Environments: A Comparative Study between the Guadalquivir Valley (Spain) and the Apulia Region. Forests 2021, 12, 1201. [CrossRef]

13. Scarascia-Mugnozza, G.; Oswald, H.; Piussi, P.; Radoglou, K. Forests of the Mediterranean region: Gaps in knowledge and research needs. For. Ecol. Manag. 2000, 132, 97-109. [CrossRef]

14. Rincón, A.M.; Pérez-Izquierdo, L.; de Miguel, S.; Parladé, J. Mycorrhizae in Mediterranean Pine and Mixed Forests. In Pines and Their Mixed Forest Ecosystems in the Mediterranean Basin; Ne'eman, G., Osem, Y., Eds.; Springer: Cham, Switzerland, 2021; Volume 38.

15. Büntgen, U.; Kauserud, H.; Egli, S. Linking climate variability to mushroom productivity and phenology. Front. Ecol. Environ. 2012, 10, 14-19. [CrossRef]

16. Grainger, J. Ecology of the larger fungi. Trans. Br. Mycol. Soc. 1946, 29, 52-63. [CrossRef]

17. Parker-Rhodes, A.F. The Basidiomycetes of Skokholm Island VII. Some floristic and ecological calculations. New Phytol. 1951, 50, 227-243. [CrossRef]

18. Richardson, M. Studies of Russula emetica and other agarics in a Scots pine plantation. Trans. Br. Mycol. Soc. 1970, 55, 217-229. [CrossRef]

19. Zervakis, G.I.; Polemis, E.; Dimou, D.M. Mycodiversity studies in selected ecosystems of Greece: III. Macrofungi recorded in Quercus forests from southern Peloponnese. Mycotaxon 2002, 84, 141-162.

20. Richard, F.; Moreau, P.A.; Selosse, M.A.; Gardes, M. Diversity and fruiting patterns of ectomycorrhizal and saprobic fungi in an old-growth Mediterranean forest dominated by Quercus ilex L. Can. J. Bot. 2004, 82, 1711-1729. [CrossRef]

21. Dimou, D.M.; Polemis, E.; Konstantinidis, G.; Kaounas, V.; Zervakis, G.I. Diversity of macrofungi in the Greek islands of Lesvos and Agios Efstratios, NE Aegean Sea. Nova Hedwig. 2016, 102, 439-475. [CrossRef]

22. Mehus, H. Fruit Body Production of Macrofungi in Some North Norwegian Forest Types. Nord. J. Bot. 1986, 6, 679-702. [CrossRef] 
23. IPCC. Climate Change 2013: The Physical Science Basis. Contribution of Working Group I to the Fifth Assessment Report of the Intergovernmental Panel on Climate Change; Stocker, T.F., Qin, D., Plattner, G.-K., Tignor, M., Allen, S.K., Boschung, J., Nauels, A., Xia, Y., Bex, V., Midgley, P.M., et al., Eds.; Cambridge University Press: Cambridge, UK; New York, NY, USA, 2013; 1535p.

24. Gange, A.C.; Gange, E.G.; Sparks, T.H.; Boddy, L. Rapid and recent changes in fungal fruiting patterns. Science 2007, $316,71$. [CrossRef] [PubMed]

25. Kauserud, H.; Heegaard, E.; Büntgen, U.; Halvorsen, R.; Egli, S.; Senn-Irlet, B.; Høiland, K. Warming-induced shift in European mushroom fruiting phenology. Proc. Natl. Acad. Sci. USA 2012, 109, 14488-14493. [CrossRef]

26. Martiny, J.B.; Bohannan, B.J.; Brown, J.H.; Colwell, R.K.; Fuhrman, J.A.; Green, J.L.; Horner-Devine, M.C.; Kane, M.; Krumins, J.A.; Kuske, C.R.; et al. Microbial biogeography: Putting microorganisms on the map. Nat. Rev. Microbiol. 2006, 4, 102-112. [CrossRef] [PubMed]

27. Buée, M.; De Boer, W.; Martin, F.; Van Overbeek, L.; Jurkevitch, E. The rhizosphere zoo: An overview of plant-associated communities of microorganisms, including phages, bacteria, archaea, and fungi, and of some of their structuring factors. Plant Soil 2009, 321, 189-212. [CrossRef]

28. Aponte, C.; García, L.V.; Marañón, T.; Gardes, M. Indirect host effect on ectomycorrhizal fungi: Leaf fall and litter quality explain changes in fungal communities on the roots of co-occurring Mediterranean oaks. Soil Biol. Biochem. 2010, 42, 788-796. [CrossRef]

29. Robertson, G.P.; Crum, J.R.; Ellis, B.G. The spatial variability of soil resources following long-term disturbance. Oecologia 1993, 96, 451-456. [CrossRef]

30. Hering, T.F. The terricolous higher fungi of four lake district woodlands. Trans. Br. Mycol. Soc. 1966, 49, 369-383. [CrossRef]

31. Durall, D.M.; Gamiet, S.; Simard, S.W.; Kudrna, L.; Sakakibara, S.M. Effects of clearcut logging and tree species composition on the diversity and community composition of epigeous fruit bodies formed by ectomycorrhizal fungi. Can. J. Bot. 2006, 84, 966-980. [CrossRef]

32. Halme, P.; Heilmann-Clausen, J.; Rämä, T.; Kosonen, T.; Kunttu, P. Monitoring fungal biodiversity-Towards an integrated approach. Fungal Ecol. 2012, 5, 750-758. [CrossRef]

33. Langer, E.; Langer, G.; Striegel, M.; Riebesehl, J.; Ordynets, A. Fungal diversity of the Kellerwald-Edersee National Park-indicator species of nature value and conservation. Nova Hedwig. 2014, 99, 129-144. [CrossRef]

34. Watling, R. Assessment of fungal diversity: Macromycetes, the problems. Can. J. Bot. 1995, 73 (Suppl. S1), S515-S524. [CrossRef]

35. Angelini, P.; Compagno, R.; Arcangeli, A.; Bistocchi, G.; Gargano, M.L.; Venanzoni, R.; Venturella, G. Macrofungal diversity and ecology in two Mediterranean forest ecosystems. Plant Biosyst. 2016, 150, 540-549. [CrossRef]

36. Salerni, E.; Laganà, A.; Perini, C.; Loppi, S.; de Dominicis, V. Effects of temperature and rainfall on fruiting of macrofungi in oak forests of the Mediterranean area. Isr.J. Plant Sci. 2002, 50, 189-198. [CrossRef]

37. García Jiménez, P.; Fernández Ruiz, A.; Sánchez Sánchez, J.; Rodríguez de la Cruz, D. Mycological Indicators in Evaluating Conservation Status: The Case of Quercus spp. Dehesas in the Middle-West of the Iberian Peninsula (Spain). Sustainability 2020, 12, 10442. [CrossRef]

38. Azul, A.M.; Castro, P.; Sousa, J.P.; Freitas, H. Diversity and fruiting patterns of ectomycorrhizal and saprobic fungi as indicators of land-use severity in managed woodlands dominated by Quercus suber-A case study from southern Portugal. Can. J. For. Res. 2009, 39, 2404-2417. [CrossRef]

39. Crusafont, M.; Truyols, J. Algunas precisiones sobre la edad y extensión del Paleógeno de las provincias de Salamanca y Zamora. Cursos Conf. Inst. Lucas Mallada 1958, 4, 83-85.

40. García-Rodríguez, A.; Forteza, J.; Prat-Pérez, L.; Gallardo, J.F.; Lorenzo-Martín, L.F. Suelos. Estudio integrado y multidisciplinario de la dehesa salmantina 1. Estudio fisiográfico descriptivo. Cons. Super. Investig. Científicas Salamanca-Jaca. 1979, 3, 65-100.

41. Fernández, A.; Sánchez, S.; García, P.; Sánchez, J. Macrofungal diversity in an isolated and fragmented Mediterranean Forest ecosystem. Plant Biosyst. 2020, 154, 139-148. [CrossRef]

42. Capel Molina, J.J. Los climas de España; Oikos-tau S.A.: Barcelona, Spain, 1981.

43. Barbancho, A.C.; Tejeda, E.M.; Hernández, M.Q. Evolución de las temperaturas y precipitaciones en las capitales de Castilla y León en el período 1961-2006. Polígonos. Rev. Geogr. 2012, 17, 59-81. [CrossRef]

44. Feest, A. Establishing baseline indices for the quality of the biodiversity of restored habitats using a standardized sampling process. Restor. Ecol. 2006, 14, 112-122. [CrossRef]

45. CABI Index Fungorum. Available online: http://www.indexfungorum.org/names/names.asp (accessed on 8 December 2021).

46. Kirk, P.M.; Cannon, P.; Minter, D.; Stalpers, J. Dictionary of the Fungi, 10th ed.; CAB International: Wallingford, UK, 2008.

47. Sarkar, S. Defining "biodiversity": Assessing biodiversity. Monist 2002, 85, 131-155. [CrossRef]

48. Magurran, A.E. Measuring Biological Diversity; Blackwell: Malden, MA, USA, 2004.

49. Cowling, R.M.; Rundel, P.W.; Lamont, B.B.; Arroyo, M.K.; Arianoutsou, M. Plant diversity in Mediterranean-climate regions. Trends Ecol. Evol. 1996, 11, 362-366. [CrossRef]

50. Oreja, J.G.; de la Fuente-Díaz-Ordaz, A.A.; Hernández-Santín, L.; Buzo-Franco, D.; Bonache-Regidor, C. Evaluación de estimadores no paramétricos de la riqueza de especies. Un ejemplo con aves en áreas verdes de la ciudad de Puebla, México. Anim. Biodivers. Conserv. 2010, 33, 31-45.

51. Basualdo, C.V. Choosing the best non-parametric richness estimator for benthic macroinvertebrates databases. Rev. Soc. Entomol. Argent. 2011, 70, 27-38. 
52. Colwell, R.K. EstimateS: Statistical Estimation of Species Richness and Shared Species from Samples, Version 8. User's Guide and Application. 2006. Available online: http:// purl.oclc.org/estimates (accessed on 1 September 2021).

53. Gotelli, N.J.; Colwell, R.K. Quantifying bio-diversity: Procedures and pitfalls in the measurement and comparison of species richness. Ecol. Lett. 2001, 4, 379-391. [CrossRef]

54. Díaz-Frances, E.; Soberón, J. Statistical estimation and model selection of species-accumulation functions. Conserv. Biol. 2005, 19, 569-573. [CrossRef]

55. Chao, A. Estimating the population size for capture-recapture data with unequal catchability. Biometrics 1987, $43,783-791$. [CrossRef]

56. Oksanen, J.; Blanchet, F.G.; Friendly, M.; Kindt, R.; Legendre, P.; McGlinn, D.; Minchin, P.R.; O’Hara, R.B.; Simpson, G.L.; Solymos, P.; et al. R Package Version 2.4-0. Vegan: Community Ecology Package. 2016. Available online: https://cran.r-project.org/ web/packages/vegan/index.html (accessed on 1 September 2021).

57. Vicente-Villardón, J.L. MultBiplot(R): Multivariate Analysis using Biplots. R Package Version 0.3.3. 2016. Available online: https:/ / biplot.usal.es/classicalbiplot/multbiplot-in-r/ (accessed on 1 September 2021).

58. Gallego-Álvarez, I.; Vicente-Villardón, J.L. Analysis of environmental indicators in international companies by applying the logistic biplot. Ecol. Indic. 2012, 23, 250-261. [CrossRef]

59. Shi, L.L.; Mortimer, P.E.; Slik, J.F.; Zou, X.M.; Xu, J.; Feng, W.T.; Qiao, L. Variation in forest soil fungal diversity along a latitudinal gradient. Fungal Divers. 2014, 64, 305-315. [CrossRef]

60. Ágreda, T.; Águeda, B.; Olano, J.M.; Vicente-Serrano, S.M.; Fernández-Toirán, M. Increase evapotranspiration demand in a Mediterranean climate might cause a decline in fungal yields under global warming. Glob. Chang. Biol. 2015, 21, 3499-3510. [CrossRef] [PubMed]

61. Barnes, C.J.; Van der Gast, C.J.; McNamara, N.P.; Rowe, R.; Bending, G.D. Extreme rainfall affects assembly of the root-associated fungal community. New Phytol. 2018, 220, 1172-1184. [CrossRef]

62. Jang, S.K.; Kim, S.W. Relationship between Ectomycorrhizal Fruiting Bodies and Climatic and Environmental Factors in Naejangsan National Park. Mycobiology 2015, 43, 122-134. [CrossRef]

63. Sun, Q.; Liu, Y.; Yuan, H.; Lian, B. The effect of environmental contamination on the community structure and fructification of ectomycorrhizal fungi. MicrobiologyOpen 2017, 6, e00396. [CrossRef] [PubMed]

64. Baptista, P.; Martins, A.; Tavares, R.M.; Lino-Nieto, T. Diversity and fruiting pattern of macrofungi associated with chestnut (Castanea sativa) in the Trás-os-Montes region (Northeast Portugal). Fungal Ecol. 2010, 3, 9-19. [CrossRef]

65. Kauserud, H.; Stige, L.C.; Vik, J.O.; Økland, R.H.; Høiland, K.; Stenseth, N.C. Mushroom fruiting and climate change. Proc. Natl. Acad. Sci. USA 2008, 105, 3811-3814. [CrossRef] [PubMed]

66. Martin, L.M.; Polley, H.W.; Daneshgar, P.P.; Harris, M.A.; Wilsey, B.J. Biodiversity, photosynthetic mode, and ecosystem services differ between native and novel ecosystems. Oecologia 2014, 175, 687-697. [CrossRef] [PubMed]

67. Malcolm, J.R.; Liu, C.; Neilson, R.P.; Hansen, L.; Hannah, L. Global warming and extinctions of endemic species from biodiversity hotspots. Conserv. Biol. 2006, 20, 538-548. [CrossRef] [PubMed]

68. Allard, V.; Ourcival, J.M.; Rambal, S.; Joffre, R.; Rocheteau, A. Seasonal and annual variation of carbon exchange in an evergreen Mediterranean forest in southern France. Glob. Chang. Biol. 2008, 14, 1-12. [CrossRef]

69. Mair, L.; Jönsson, M.; Räty, M.; Bärring, L.; Strandberg, G.; Lämås, T.; Snäll, T. Land use changes could modify future negative effects of climate change on old-growth forest indicator species. Divers. Distrib. 2018, 24, 1416-1425. [CrossRef]

70. Markkola, A.M.; Saravesi, K.; Aikio, S.; Taulavuori, E.; Taulavuori, K. Light-driven host-symbiont interactions under hosts' range shifts caused by global warming: A review. Environ. Exp. Bot. 2016, 121, 48-55. [CrossRef]

71. Thakur, M.P.; Quast, V.; Van Dam, N.M.; Eisenhauer, N.; Roscher, C.; Biere, A.; Martinez-Medina, A. Interactions between functionally diverse fungal mutualists inconsistently affect plant performance and competition. Oikos 2019, 128, 1136-1146. [CrossRef]

72. Martinová, V.; Van Geel, M.; Lievens, B.; Honnay, O. Strong differences in Quercus robur-associated ectomycorrhizal fungal communities along a forest-city soil sealing gradient. Fungal Ecol. 2016, 20, 88-96. [CrossRef]

73. Martin, F.; Cullen, D.; Hibbett, D.; Pisabarro, A.; Spatafora, J.W.; Baker, S.E.; Grigoriev, I.V. Sequencing the fungal tree of life. New Phytol. 2011, 190, 818-821. [CrossRef] [PubMed]

74. Hawkes, C.V.; Kivlin, S.N.; Rocca, J.D.; Huguet, V.; Thomsen, M.A.; Suttle, K.B. Fungal community responses to precipitation. Glob. Chang. Biol. 2011, 17, 1637-1645. [CrossRef]

75. Zelnik, Y.R.; Meron, E.; Bel, G. Localized states qualitatively change the response of ecosystems to varying conditions and local disturbances. Ecol. Complex. 2016, 25, 26-34. [CrossRef]

76. Hui, N.; Liu, X.; Jumpponen, A.; Setälä, H.; Kotze, D.J.; Biktasheva, L.; Romantschuk, M. Over twenty years farmland reforestation decreases fungal diversity of soils, but stimulates the return of ectomycorrhizal fungal communities. Plant Soil. 2018, 427, 231-244. [CrossRef]

77. Bazzaz, F.A. The response of natural ecosystems to the rising global $\mathrm{CO}_{2}$ levels. Annu. Rev. Ecol. Evol. Syst. 1990, 21, 167-196. [CrossRef]

78. Kern, M.; Caldararu, S.; Engel, J.; Rammig, A.; Vicca, S.; Zaehle, S. A novel plant-mycorrhiza interaction model improves representation of plant responses to elevated $\mathrm{CO}_{2}$. In Proceedings of the 20th EGU General Assembly, EGU2018, Vienna, Austria, 4-13 April 2018; p. 7526. 
79. Pickles, B.J.; Egger, K.N.; Massicotte, H.B.; Green, D.S. Ectomycorrhizas and climate change. Fungal Ecol. 2012, 5, 73-84. [CrossRef]

80. Morgado, L.N.; Semenova, T.A.; Welker, J.M.; Walker, M.D.; Smets, E.; Geml, J. Summer temperature increase has distinct effects on the ectomycorrhizal fungal communities of moist tussock and dry tundra in Arctic Alaska. Glob. Chang. Biol. 2015, 21, 959-972. [CrossRef]

81. Akroume, E.; Maillard, F.; Bach, C.; Hossann, C.; Brechet, C.; Angeli, N.; Zeller, B.; Saint-André, L.; Buée, M. First evidences that the ectomycorrhizal fungus Paxillus involutus mobilizes nitrogen and carbon from saprotrophic fungus necromass. Environ. Microbiol. 2018, 21, 197-208. [CrossRef]

82. Egerton-Warburton, L.M.; Johnson, N.C.; Allen, E.B. Mycorrhizal community dynamics following nitrogen fertilization: A cross-site test in five grasslands. Ecol. Monogr. 2007, 77, 527-544. [CrossRef]

83. Terrer, C.; Vicca, S.; Stocker, B.D.; Hungate, B.A.; Phillips, R.P.; Reich, P.B.; Finzi, A.C.; Prentice, C.P. Ecosystem responses to elevated $\mathrm{CO}_{2}$ governed by plant-soil interactions and the cost of nitrogen acquisition. New Phytol. 2017, 217, 507-522. [CrossRef] [PubMed]

84. Gonçalves, S.C.; Haelewaters, D.; Furci, G.; Mueller, G.M. Include all fungi in biodiversity goals. Science 2021, 373, 403. [CrossRef] [PubMed]

85. Mueller, G.M.; Schmit, J.P.; Leacock, P.R.; Buyck, B.; Cifuentes, J.; Desjardin, D.E.; Halling, R.E.; Hjortstam, K.; Iturriaga, T.; Larsson, K.H.; et al. Global diversity and distribution of macrofungi. Biodivers. Conserv. 2007, 16, 37-48. [CrossRef]

86. Arnolds, E. The future of fungi in Europe: Threats, conservation and management. Br. Mycol. Symp. Ser. 2001, $22,64-80$.

87. Cannon, P.F.; Mibey, R.K.; Siboe, G.M. Microfungus diversity and the conservation agenda in Kenya. Br. Mycol. Symp. Ser. 2001, 22, 197-208.

88. Piazza, G.; Ercoli, L.; Nuti, M.; Pellegrino, E. Interaction between conservation tillage and nitrogen fertilization shapes prokaryotic and fungal diversity at different soil depths: Evidence from a 23-year field experiment in the Mediterranean Area. Front. Microbiol. 2019, 10, 2047. [CrossRef]

89. Girometta, C.E.; Bernicchia, A.; Baiguera, R.M.; Bracco, F.; Buratti, S.; Cartabia, M.; Picco, A.M.; Savino, E. An Italian research culture collection of wood decay fungi. Diversity 2020, 12, 58. [CrossRef]

90. De la Varga, H.; Águeda, B.; Ágreda, T.; Martínez-Peña, F.; Parladé, J.; Pera, J. Seasonal dynamics of Boletus edulis and Lactarius deliciosus extraradical mycelium in pine forests of central Spain. Mycorrhiza 2013, 23, 391-402. [CrossRef]

91. Halme, P.; Kotiaho, J.S. The importance of timing and number of surveys in fungal biodiversity research. Biodivers. Conserv. 2012, 21, 205-209. [CrossRef]

92. Zamora, J.C.; Svensson, M.; Kirschner, R.; Olariaga, I.; Ryman, S.; Parra, L.A.; Geml, J.; Rosling, A.; Adamčík, S.; Ahti, T.; et al. Considerations and consequences of allowing DNA sequence data as types of fungal taxa. IMA Fungus 2018, 9, 167-175. [CrossRef]

93. Rey-Benayas, J.M.; Scheiner, S.M. Plant diversity, biogeography and environment in Iberia: Patterns and possible causal factors. J. Veg. Sci. 2002, 13, 245-258. [CrossRef]

94. Teobaldelli, M.; Cona, F.; Saulino, L.; Migliozzi, A.; D’Urso, G.; Langella, G.; Manna, P.; Saracino, A. Detection of diversity and stand parameters in Mediterranean forests using leaf-off discrete return LiDAR data. Remote Sens. Environ. 2017, 192, 126-138. [CrossRef]

95. Clavería, V.; de Miguel, A.M. Diversidad ectomicorrícica en una formación natural de carrasca (Quercus ilex L. subsp. ballota (Desf.) Samp.). In Actas del $4^{\circ}$ Congreso Forestal Español; Sociedad Española de Ciencias Forestales: Zaragoza, Spain, 2005.

96. Sarrionandia, E.; Salcedo, I. Macrofungal diversity of holm-oak forests at the northern limit of their distribution range in the Iberian Peninsula. Scand. J. For. Res. 2018, 33, 23-31. [CrossRef]

97. Carrie, A.; Heegaard, E.; Høiland, K.; Senn-Irlet, B.; Kuyper, T.W.; Krisai-Greilhuber, I.; Kirk, P.M.; Heilmann-Clausen, J.; Gange, A.C.; Egli, S.; et al. Explaining European fungal fruiting phenology with climate variability. Ecology 2018, 99, 1306-1315.

98. Bahnmann, B.; Mašínová, T.; Halvorsen, R.; Davey, M.L.; Sedlák, P.; Tomšovský, M.; Baldrian, P. Effects of oak, beech and spruce on the distribution and community structure of fungi in litter and soils across a temperate forest. Soil Biol. Biochem. 2018, 119, 162-173. [CrossRef]

99. Moreno, G.; Manjón, J.L.; Álvarez-Jiménez, J. Hypogeous desert fungi. In Desert Truffles; Kagan-Zur, V., Sitrit, Y., Roth-Bejerano, N.A., Morte, A., Eds.; Springer: Berlin, Germany, 2013; pp. 129-135.

100. Abrego, N.; Halme, P.; Purhonen, J.; Ovaskainen, O. Fruit body based inventories in wood-inhabiting fungi: Should we replicate in space or time? Fungal Ecol. 2016, 20, 225-232. [CrossRef]

101. Ambrosio, E.; Mariotti, M.G.; Zotti, M.; Cecchi, G.; Di Piazza, S.; Feest, A. Measuring macrofungal biodiversity quality using two different survey approaches: A case study in broadleaf Mediterranean forests. Ecol. Indic. 2018, 85, 1210-1230. [CrossRef]

102. Walther, B.A.; Moore, J.L. The concepts of bias, precision, and accuracy, and their use in testing the performance of species richness estimators, with a literature review of estimator performance. Ecography 2005, 28, 815-829. [CrossRef]

103. Cannon, P. Options and constraints in rapid diversity analysis of fungi in natural ecosystems. Fungal Divers. 1999, 2, 1-15.

104. Hyde, K.D. Can we rapidly measure fungal diversity? Mycologist 1997, 11, 176-178. [CrossRef]

105. Manzo, S. Experimentación, instrumentos científicos y cuantificación en el método de Francis Bacon. Manuscrito 2001, 24, 49-84. 